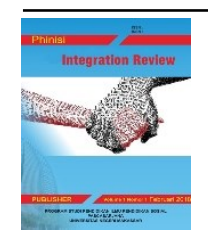

Phinisi Integration Review

Vol. 4, No.1, Februari 2021 Hal 55-63

Website: http://ojs.unm.ac.id/pir

p-ISSN: 2614-2325 dan e-ISSN: 2614-2317

DOI: https://doi.org/10.26858/pir.v4i1.19339

\title{
Pola Perilaku Menyimpang Peserta Didik di SDN 350 Kahaya Kecamatan Kindang Kabupaten Bulukumba
}

\author{
Andi Asriani \\ SDN 350 Kahaya Bulukumba, Indonesia \\ Email: Andiasriani28@gmail.com
}

\begin{abstract}
Penelitian ini bertujuan untuk mengetahui bentuk-bentuk pola perilaku menyimpang Siswa di SDN 350 Kahaya Kecamatan Kindang Kabupaten Bulukumba dan untuk mengetahui faktor-faktor penyebab terjadinya perilaku menyimpang Siswa diSDN 350 Kahaya Kecamatan Kindang Kabupaten Bulukumba serta mengetahui upaya-upaya yang dilakukan guru dalam mengatasi perilaku menyimpang siswa di SDN 350 KahayaKecamatanKindang Kabupaten Bulukumba.Jenis penelitian yang digunakan dalam penelitian ini adalah deskriptifkualitatif, yaitu suatu proses pengumpulan data secara sistematis dan intensifuntuk memperoleh pengetahuan dan informasi. Maka dalam penelitian inipeneliti mengamati dan berinteraksi dengan wali kelas, dan siswa-siswi SDN 350 KahayaKecamatan Kindang Kabupaten Bulukumba dengan wawancara dan mencari data dengan mengkaji dokumentasinya.Berdasarkan hasil penelitian menunjukkan bahwabentuk-bentuk penyimpangan yang dilakukan siswa di SDN 350 KahayaKecamatanKindang Kabupaten Bulukumba antara lain: berkelahi, bolos, keluyuran. Faktor-faktor yang mempengaruhi pola perilaku siswa di SDN 350 Kahaya Kecamatan Kindang Kabupaten Bulukumba antara lain adanya masalah dalam keluarga, kondisi sosial ekonomi keluarga, faktor lingkungan pergaulan dan faktor internal dalam diri siswa. Upaya yang dilakukan guru dalam mengatasi perilaku menyimpang siswa di SDN 350 KahayaKecamatanKindang Kabupaten Bulukumba, pihak sekolah memberikan sanksi-sanksi khusus sesuai dengan peraturan yang telah ada. Sanksi yang paling sering digunakan untuk mengatasi masalah penyimpangan yang dilakukan siswa adalah pemanggilan orang tua ke sekolah dan memberikan pembinaan kepada siswa yang bersangkutan.
\end{abstract}

Kata Kunci: pola perilaku menyimpang, Siswa.

Abstract. This research aims to know the forms of deviant behavior patterns students at
SDN 350 Kahaya District Kindang Bulukumba District and to know the factors of the cause
of aberrant behavior students at SDN 350 Kahaya District Kindang Regency Bulukumba
and know the efforts of the teachers in overcoming the deviant behavior of students at SDN
350 Kahaya District Kindang District Bulukumba. The type of research used in this study
is a qualitative descriptive, which is a systematic and intensive data collection process for
obtaining knowledge and information. So in this research researchers observe and interact
with the school principal, Guardian, and students of SDN 350 Kahaya subdistrict Kindang
District Bulukumba with interviews and search for data by reviewing its documentation.
Based on the results of the study showed that the forms of deviations conducted by students
at SDN 350 Kahaya Kindang subdistrict Bulukumba District among others: fighting, brawl,
smoking, drinking liquor, gambling, bolos, fees, behavior Asusila, opposed teachers.
Factors affecting the behavior patterns of students at SDN 350 Kahaya in Kindang sub-
district, Bulukumba, among others, have problems in family, socio-economic conditions,
social environment factors and internal factors in students. The efforts of the teachers in 
overcoming the deviant behaviour of students at SDN 350 Kahaya, Kindang District Bulukumba District, the school gave special sanctions in accordance with the existing regulations. The most frequent sanctions used to address the problem of deviations by students are the calling of parents to school and providing coaching to the student in question.

Keywords: deviant behavior patterns, students.

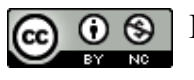

Ini adalah artikel dengan akses terbuka dibawah licenci CC BY-NC-4.0 (https://creativecommons.org/licenses/by-nc/4.0/).

\section{PENDAHULUAN}

Aspek pendidikan dapat diartikan sebagai sesuatu yang sangat penting bagi semua manusia, karena manusia lahir dalam keadaan yang tidak mempunyai apa-apa dan tidak tahu sesuatu apapun. Dengan pendidikanlah manusia dapat memiliki kemampuan pengetahuan dan juga kepribadian yang selalu berkembang, sebagaimana dituangkan dalam Undang-undang Sistem Pendidikan Nasional Nomor 20 tahun 2003 khusunya pasal 3 yang menyatakan bahwa pendidikan nasional berfungsi menembangkan kemampuan dan membentuk watak serta peradaban bangsa, bertujuan untuk berkembangnya potensi peserta didik agar menjadi manusia yang beriman dan bertaqwa kepada Tuhan Yang Maha Esa, berakhlak mulia, sehat, berilmu, cakap, kreatif, mandiri ,dan warga negara yang demokratis serta bertanggung jawab.

Ketika terjadi perubahan dengan cepat, salah satu kelompok yang rentang untuk ikut terbawa arus adalah para remaja. Dalam perspektif psikologi perkembangan, masa remaja memang masa yang berbahaya, karena pada masa ini seorang mengalami masa transisi atau peralihan dari masa kehidupan anak-anak menuju kedewasaan yang sering ditandai dengan krisis kepribadian. Perubahan- perubahan fisik dan psikis yang sangat cepat menyebabkan kegelisahan- kegelisahan internal, misalnya perubahan peranan, timbul rasa tertekan,dorongan untuk mendapatkan kebebasan, kegoncangan emosional, rasa ingin tahu yang menonjol,adanya fantasi yang berlebihan, ikatan kelompok yang kuat dan krisis identitas (Kartono, 1998:12).

Apapun bentuk ekspresi kejiwaan remaja yang diperlukan adalah tempat penyaluran yang sehat. Kebutuhan efektifitas sosial, melakukan sosialisasi kelompok untuk memenuhi kebutuhan aktualisasi dirinya. Mereka ingin dianggap kehadirannya dalam wujud apresiatif dan butuh penghargaan. Apa bila hal ini tidak terwujud maka penyaluran potensi dirinya itu terlepas dalam bentuk perilaku menyimpang. Perilaku menyimpang yang dilakukan anak-anak muda remaja pada intinya merupakan produk dari kondisi masyarakatnya dengan segala pergolakan sosial yang ada didalamnya.

Permasalahan ini mengindikasikan bahwa siswa saat ini cenderung mengalami gangguan psikologis atau tampil dengan kondisi emosional yang tempramental, mudah terprovokasi dan tidak terkendali. Sesuai yang diungkapkan Fitri (2012: 10) bahwa remaja khususnya siswa SD dewasa ini sudah begitu banyak diberitakan di media dengan berbagai macam penyimpangan seperti tawuran, penyalahgunaan narkoba, pergaulan bebas, dan seterusnya. Selain itu, mereka juga terkesan kurang hormat kepada orang tua, guru, dan tokoh masyarakat.

\section{TINJAUAN PUSTAKA}

\section{A. Landasan Teori \\ 1. Pengertian Pola Perilaku Menyimpang}

Secara etismologi, pola adalah bentuk (struktur) yang tetap dalam kamus bahasa Indonesia.org/pola.Berdasarkan definisi tersebut, maka dapat disimpulkan bahwa pola adalah suatu bentuk, struktur atau gambaran dari sesuatu. Perilaku menyimpang dapat diartikan sebagai tingkah laku yang melanggaratau bertentangan dengan aturan normatif dan pengertian normative maupun dari harapan-harapan lingkungan sosial yang bersangkutan. Menurut 
Robert M.Z. Lawang dalam Sadli (1976:35), perilaku menyimpang adalah semua tindakan yang menyimpang dari norma yang berlaku dalam sistem sosial dan menimbulkan usaha dari mereka yang berwenang dalam sistem itu untuk memperbaiki perilaku menyimpang. Menurut Lemert penyimpangan dapat dibedakan menjadi dua macam, yaitu penyimpangan primer dan penyimpangan sekunder.

Penyimpangan primer adalah suatu bentuk perilaku menyimpang yang bersifat sementara dan tidak dilakukan terus-menerus sehingga masih dapat ditolerir masyarakat seperti melanggar lalu lintas, buang sampah sembarangan,dan lain-lain. Sedangkan penyimpangan sekunder yakni perilaku menyimpang yang tidak mendapat toleransi dari masyarakat dan umumnya dilakukan berulang kali seperti merampok, menjambret, memakai narkoba, menjadi pelacur, tawuran dan lain-lain.

\section{Perilaku Menyimpang sebagai Masalah Sosial}

Perilaku menyimpang ini disebut sebagai salah satu penyakit masyarakat atau penyakit sosial. Penyakit sosialatau penyakit masyarakat adalah segala bentuk tingkah laku yang dianggap tidak sesuai,melanggar norma-norma umum, adat-istiadat, hukum formal, atau tidak bisa diintegrasikan dalam pola tingkah- laku umum. Disebut sebagai penyakit masyarakat karena gejala sosialnya yang terjadi di tengah masyarakat itu meletus menjadi"penyakit". Dapat disebut pula sebagai struktur sosial yang terganggu fungsinya, disebabkan oleh faktor-faktor sosial.

Jadi, norma-norma sosial adalah apa yang harus dan dilarang dalam masyarakat. Norma-norma tersebut diciptakan dan dibentuk karena individu sebagai anggota masyarakat saling berhubungan dan berinteraksi. Selanjutnya norma tersebut berfungsi untuk mengarahkan, menyalurkan, dan membatasi hubungan-hubungan anggota masyarakat pada umumnya.

Menurut Thorsten Sellin, norma-norma yang mengatur kehidupan kita sehari-hari merupakan aturan-aturan yang merefleksikan sikap-sikap kelompok yang masing-masing kita memilikinya. Tujuan dari norma tersebut adalah untuk mendefenisikan apa yang dianggap sebagai tingkah laku yang pantas atau normal dan apa yang dianggap tingkah laku yang tidak pantas atau abnormal (Santoso, 2005:79).
Dalam hal ini perilaku yang menyimpang dari norma-norma yang berlaku dalam suatu sistem sosial dibedakan atas empat macam yaitu: (1) Perilaku menyimpang yang dilihat dan dianggap sebagai kejahatan; (2) Penyimpangan seksual dalam arti perilaku yang lain dari biasanya; (3) Bentuk-bentuk konsumsi yang berlebihan, misalnya alcohol; (4) Gaya hidup yang lain dari yang lain.

Akan tetapi penyimpangan apapun yang terjadi haruslah selalu dilihat dari segi dimana dalam suatu masyarakat tertentu telah digariskan terlebih dahulu apa yang normal terhadap masyarakat itu. Dasarnya adalah bahwa penyimpangan itu tidak selalu sama untuk setiap masyarakat.

\section{Bentuk-Bentuk Perilaku Menyimpang}

Kenakalan yang bersifat melanggar hukum dengan penyelesaian sesuai dengan undangundang dan hukum yang berlaku sama dengan perbuatan melanggar hukum bilamana dilakukan oleh orang dewasa yaitu:

a) Perjudian dan segala macam bentuk perjudian yang mempergunakan uang.

b) Pencurian dengan kekerasan maupun tanpa kekerasan: pencopetan, perampasan, dan penjambretan.

c) Penggelapan barang.

d) Penipuan dan pemalsuan

e) Pelanggaran tata susila, menjual gambargambar porno dan film porno, serta pemerkosaan.

f) Tindakan-tindakan anti sosial, perbuatan yang merugikan milik orang lain.

g) Percobaan pembunuhan.

h) Pengguguran kandungan.

\section{Penyebab Perilaku Menyimpang}

Di Indonesia, secara umum penyimpangan perilaku pada remaja diartikan sebagai kenakalan remaja atau juveniledelinquency. Penyimpangan perilaku remaja ini mempunyai sebab musabab yang majemuk, sehingga sifatnya mulai kasual.

Kartini Kartono mengemukakan bahwa, anak-anak remaja yang melakukan kejahatan itu pada umumnya kurang memiliki kontrol diri, atau justru menyalah gunakan control diri tersebut, dan suka menegakkan standar tingkah laku sendiri, disamping meremehkan keberadaan orang lain. Kejahatan yang mereka lakukan itu pada umumnya disertai unsur-unsur metal dengan motif-motif subjektif, yaitu untuk mencapai satu subjek tertentu dengan disertai kekerasan dan agresif. Pada umumnya anak-anak 
muda tadi sangat egoistis, dan suka sekali menyalah gunakan dan melebih-lebihkan harga dirinya.

\section{Upaya Mengatasi Perilaku Menyimpang Siswa}

Langkah-langkah yang perlu dilakukan untuk mengembalikan kegoyahan tersebut, terutama pada generasi muda yang terjepit antara norma lama dan norma baru adalah dengan jalan mengadakan inventarisasi pengalamanpengalaman dan kerjasama antara para ahli teknik dan para ahli bidang sosial, untuk mengadakan seleksi masuknya unsur-unsur yang baru dan diintegrasikan dengan unsu-unsur lama. Disamping itu juga mengadakan perencanaan sosial (social planing) dan bertujuan untuk menghilangkan atau membatasi keterbelakangan unsur-unsur kebudayaan material atau teknologi, sebab problema sosial dewasa ini disebabkan oleh keterbelakangan tersebut, yang mengakibatkan penyalahgunaan sumber-sumber alam, demoralisasi kehidupan keluarga, angka kejahatan yang tinggi, sakit jiwa.dengan usaha itu diharapkan tercipta suatu keseimbangan dalam masyarakat (social Equilibrium). (Y. Bambang Mulyono, 1993:51-52).

\section{METODE}

Penelitiani ni adalah penelitian kualtatif deskriptif dan dapat diartikan sebagai prosedur pemecahan masalah yang diselidiki dengan menggambarkan keadaan subjek atau objek penelitian (siswa, guru masyarakat, dan lain-lain) pada saat sekarang berdasarkan fakta-fakta atau sebagaimana adanya (Nawawi,1998:63). Hal yang mendasari mengapa peneliti menggunakan penelitian kualitatif karena permasalahan yang diteliti belum jelas, bersifat menyeluruh (holistic), sangat kompleks, dan dinamis, serta penuh makna, sehingga tidak mungkin data pada situasi sosial tersebut dapat dijaring dengan penelitian kuantitatif.

Penelitian ini bertujuan untuk menggambarkan realitas tentang perilaku menyimpang siswa di SDN 350 Kahaya Kecamatan Kindang Kabupaten Bulukumba berdasarkan data dan fakta yang ada dilapangan.

Adapun yang menjadi sumber data dari penelitian ini yaitu siswa, guru bidang konseling,dan kepala sekolah.

Sumber data dalam penelitian ini adalah informan dan fenomena/kegiatan yang memberikan informasi atau keterangan yang berhubungan dengan fokus penelitian. Lebih rinci informan yang merupakan sumber data dalam penelitian ini duraikan sebagai berikut: (1) Siswa SDN 350 Kahaya Kecamatan Kindang Kabupaten Bulukumba yang berperilaku menyimpang, (2) wali kelas, kepala sekolah SDN 350 Kahaya Kecamatan Kindang Kabupaten Bulukumba.

Jenis data kualitatif yang dikumpulkan dari infoman / responden berupa pendapat, persepsi, pengalaman, pandangan yang kemudian dianalsis untuk memecahkan rumusan masalah dalam penelitian ini.

\section{Tahap-Tahap Penelitian}

Adapun tahap-tahap yang dilakukan dalam penelitian ini secara garis besar adalah sebagai berikut:

1. Tahap Pra Penelitian

1) Menyusun rancangan penelitian yang sering kita kenal dengan sebutan proposal penelitian.

2) Memilih lapangan penelitian.

3) Mengurus Perijinan

4) Menjajangi dan menilai keadaan lapangan.

5) Menyiapkan kelengkapan penelitian.

6) Etika Penelitian

\section{Tahap Pekerjaan Lapangan}

1) Memahami latar penelitian dan persiapan diri.

2) Memasuki lapangan.

3) Berperan serta sambil mengumpulkan data.

\section{Teknik Penelitian}

\section{Observasi}

Observasi atau pengamatan merupakan teknik pengumulan data dengan mengamati secara langsung sasaran (subyek) penelitian dengan merekam peristiwa dan perilaku secara wajar dan rinci.

\section{Teknik Wawancara}

Wawancara sebagai salah satu teknik pengumpulan data dipergunakan dengan tujuan untuk memperoleh data tentang perilaku menyimpang yang tidak terekam dalam observasi, untuk melengkapi serta memperdalam hasil observasi sehingga dapat mengungkapkan lebih lengkap tentang tujuan penelitian. 


\section{Dokumentasi}

Dokumen dalam penelitian ini adalah dokumen yang digunakan untuk melengkapi data yang menurut peneliti masih dibutuhkan, yaitu data yang relevan dengan fokus penelitian berupa buku rapor, buku catatan anekdok, buku penilaian afeksi, upaya bimbingan yang dilakukan guru, upaya yang dilakukan sekolah, serta foto-foto yang menggambarkan perilaku yang tampak pada kegiatan-kegiatan yang dapat memberikan bahan deskriptif.

\section{Fokus Penelitian}

1. Perilaku menyimpang di dalam penelitian ini adalah perilaku siswa yang bertentangan atau melanggar tata tertib sekolah dan normahukum.

2. Siswa yang dimaksudkan dalam penelitian ini adalah semua siswa yang mengalami perilaku menyimpang.

\section{Proses Pencatatan dan Analisis Data}

1. Proses Pencatatan

Kegiatan yang tidak kalah penting dan perlu diperhatikan oleh peneliti dalam usaha mengumpulkan informasi adalah proses pencatatan data. Alat penelitian penting yang akan digunakan dalam pengumpulan data ialah catatan lapangan, yaitu catatan yang dibuat peneliti sewaktu mengadakan wawancara, observasi, dokumentasi maupun menyaksikan suatu kejadian tertentu. Catatan lapangan dalam bentuk kata-kata kunci, singkatan, pokok-pokok utama saja, kemudian dilengkapi dan disempurnakan.

\section{Analisis Data}

Pada penelitian kualitatif, teknik yang digunakan mengacu pada teknik analisis Miles dan Huberman (Sugiyono, 2009) dilakukan secara interaktif melalui proses reduksi data, display data, interpretasi data, dan penarikan kesimpulan.

\section{Pengabsahan Data}

Keabsahan data merupakan hal penting dalam penelitian kualitatif. Pemeriksaan keabsahan data bertujuan untuk mengurangi bias yang terjadi pada saat pengumpulan data. Dalam penelitian ini, untuk memenuhi keabsahan data dengan menggunakan teknik triangulasi.Triangulasi yang akan digunakan adalah triangulasi teknik dan triangulasi sumber.
Triangulasi teknik dilakukan dengan cara mengecek data kepada sumber dengan observasi, wawancara, dan dokumentasi. Sedangkan triangulasi sumber dilakukan dengan cara mengecek data kepada sumber yang sama dengan teknik yang berbeda, yaitu dengan mewawancarai siswa, guru Pelajaran, kepala sekolah dan wakil kepala sekolah bidang kemahasiswaan. Wawancara ini dilakukan untuk mendukung hasil observasi yaitu data tentang pola perilaku menyimpang di SDN 350 Kahaya Kecamatan Kindang Kabupaten Bulukumba.

\section{HASIL DAN PEMBAHASAN}

\section{Bentuk Perilaku Menyimpang Siswa di SDN 350 Kahaya Kecamatan Kindang Kabupaten Bulukumba}

Perilaku menyimpang merupakan semuatindakanyang menyimpang darinorma yang berlaku dalam sistem sosial dan menimbulkan usaha dari mereka yang berwenang dalams istem itu untuk memperbaiki perilaku menyimpang.

Munculnya perilaku menyimpang siswa di SDN 350 Kahaya Kecamatan Kindang Kabupaten Bulukumba kerap kali terjadi karena adanya saling mempengaruhi antara siswa yang satu dengan siswa yang lainnya. Seperti yang dikemukakan oleh Ibu Andi Asriani, S.Pd selaku kepala sekolah SDN 350 KahayaKecamatanKindang Kabupaten Bulukumba bahwa:

"Biasanya penyebab siswa melakukan
masalah perilaku menyimpang
dikarenakan ada siswa yang suka
membuli,mengejek,antara siswa yang
satu dengan siswa yang lainnya
disekolah dan kadang juga dipengaruhi
oleh anak yang putus sekolah sehingga
membuat masalah seperti
berkelahi,mengajak keluyuran, dan
mengajak bolos". (Wawancara pada
hari Senin, 19 Pebruari 2020)

Dari wawancara yang dilakukan dengan kepala sekolah SDN 350 Kahaya Kecamatan Kindang Kabupaten Bulukumba, dapat diketahui bahwa siswa siswa dari SDN 350 KahayaKecamatanKindang Kabupaten Bulukumba itu sendiri yang saling mempengaruhi untuk melakukan perilaku menyimpang, tetapi biasa juga ada pengaruh-pengaruh dari anak putus sekolah yang ada disekitar lingkungan sekolah. 
Bentuk-betuk perilaku menyimpang yang dilakukan oleh siswa di SDN 350 Kahaya Kecamatan Kindang Kabupaten Bulukumba sangat beraneka ragam. Perilaku menyimpang yang paling banyak dilakukan oleh siswa adalah perkelahian. Perkelahian antara siswa biasa terjadi karena siswa berselisih paham terhadap sesuatu atau saling mengejek dan bercanda yang berlebihan. Seperti yang diungkapkan Ilham siswa kelas VI di SDN 350 KahayaKecamatanKindang Kabupaten Bulukumba bahwa:

"Perkelahian terjadi karena saya berselisih paham dengan teman".

"Sanksi yang diberikan pihak sekolah yaitu panggilan terhadap orang tua dan menghapal perkalian dan menghapal surah-surah pendek ". (Wawancara pada hari Sabtu, 21 Desember 2019)

Selain kasus perkelahian, juga biasa dilakukan oleh siswa SDN 350 Kahaya Kecamatan Kindang Kabupaten Bulukumba dengan anak yang putus sekolah. Hal ini diungkapkan oleh Winirselaku siswa kelas VI di SDN 350 Kahaya Kecamatan Kindang Kabupaten Bulukumba bahwa:

"Iya kami pernah berkelahi dengan anak yang putus sekolah".

"Kami berkelahi karena ada anak dari luar sekolah yang selalu mengejek."

"Sanksi yang kami dapat yaitu damai dengan catatan berjanji tidak bolehmengejek siswa yang lain di sekolah di SDN 350 KahayaKecamatanKindang Kabupaten Bulukumbaa untuk mencari masalah." (Wawancara pada hari Senin, 16 Desember 2019).

Perilaku menyimpang yang lain adalah perilaku menyimpang yang paling banyak dilakukan oleh siswa yakni membolos. Salah satu faktor dominan yang menjadi pemacu siswa untuk membolos adalah rasa malas mengikuti proses pembelajaran. Seperti yang diungkapkan oleh Ricky siswa kelas V di di SDN 350 KahayaKecamatanKindang Kabupaten Bulukumba a, bahwa:

"Saya membolos karena saya malas masuk belajar dan tidak mengerjakan PR".

"Sanksi yang saya terima yaitu membuat pernyataan tidak akan bolos lagi dan akan rajin mengerjakan PR (ditulis sebanyak 100 kali)." (Wawancara pada hari sabtu, 15 Pebruari 2020)

Selain membolos, perilaku menyimpang lain yang terjadi saat pembelajaran sedang berlangsung adalah keluyuran. Beberapa siswa mengaku bahwa mereka keluyuran karena diajak oleh teman-temannya. Seperti yang dikemukakan oleh Ahmad Nur siswa kelas IV di di SDN 350 Kahaya Kecamatan Kindang Kabupaten Bulukumba bahwa:

"Saya keluyuran saat jam belajar karena saya diajak teman-teman yang lain."

"Sanksi yang saya terima adalah saya di berikan pembinaan oleh kepala sekolah."'(Wawancara pada hari sabtu, 15 Pebruari 2020).

\section{Pembahasan}

\section{Bentuk Perilaku Menyimpang Siswa di di SDN 350 Kahaya Kecamatan Kindang Kabupaten Bulukumba}

Pola perilaku menyimpang dapat diartikan sebagai bentuk tingkah laku yang melanggaratau bertentangan dengan aturan normatif dan pengertian normatifmaupun dari harapan-harapan lingkungan sosial yang bersangkutan. Mengingat perubahan arus globalisasi yang dari zaman ke zaman semakin cepat, juga berdampak pada perubahan perilaku masyarakat yang lambat laun mulai mengakibatkan perubahan dilingkungan pergaulan remaja. Ketika perubahan itu terjadi, salah satu kelompok yang paling rentan mengikuti arus tersebut adalah remaja.

Masa remaja merupakan masa transisi dari kehidupan masa ank-anak menuju kedewasaan yang sering ditandai dengan krisis kepribadian.Oleh karena itu, dapat dikatakan bahwa masa remaja merupakan masa yang paling berbahaya, karena perubahan tidak hanya terjadi secara fisik tetapi juga psikis yang biasanya membawa segumpal kegelisahan dalam diri remaja. Kartono (1998: 12) menyatakan bahwa:

Perubahan- perubahan fisik dan psikis yang sangat cepat menyebabkan kegelisahan- kegelisahan internal, misalnya perubahan peranan, timbul rasa tertekan, dorongan untuk mendapatkan kebebasan, kegoncangan emosional, rasa ingin tahu yang 
menonjol, adanya fantasi yang berlebihan, ikatan kelompok yang kuat dan krisis identitas.

Berdasarkan hasil penelitian, munculnya perilaku menyimpang siswa di SDN 350 KahayaKecamatanKindang Kabupaten Bulukumba kerap kali terjadi karena adanya saling mempengaruhi antara siswa yang satu dengan siswa yang lainnya, bukan hanya dari siswa di SDN 350 Kahaya Kecamatan Kindang Kabupaten Bulukumba sendiri yang saling mempengaruhi akan tetapi biasa juga karena pengaruh-pengaruh dari anak yang tidak sekolah. Bentuk-bentuk peyimpangan yang siswa lakukan pun beraneka ragam. Singgih D. Gunarsa (2003:20) membagi kenakalan remaja itu menjadi dua kelompok besar,yaitu:

1) Kenakalan yang bersifat amoral dan asoiasi, karena tidak diatur dalam undang-undang sehingga tidak dapat atau sulit digolongkan sebagai pelanggaran hukum,yaitu:

b) Membohong, memutar balikan kenyataan dengan tujuan menipu orang atau menutupi kesalahan.

c) Membolos, pergi meninggalkan sekolah tanpa sepengetahuan pihak sekolah.

d) Kabur, meninggalkan rumah tanpa izin orang tua atau menentang keinginan orangtua.

e) Keluyuran, pergisendiri maupun berkelompok tanpa tujuan dan mudah menimbulkan perbuatan iseng yang negatif.

f) Memiliki dan membawa benda yang membahayakan orang lain, sehingga mudah terangsang untuk menggunakannya,seperti pisau, silet dan lain-lain.

g) Bergaul denganteman yang memberi pengaruh buruk, sehingga mudah terjerat dalam perkara yang benar-benar kriminal.

h) Berpestapora semalam suntuk tanpa pengawasan, sehingga mudah timbul tindakan-tindakan yang kurang bertanggung jawab (amoral dan asosial).

i) Membaca buku-buku cabul dan kebiasaan mempergunakan bahasa yang tidak sopan, tidak senonoh seolah-olah menggambarkan kurang perhatian dan pendidikan dari orang dewasa.

j) Secara berkelompok makan dirumah makan, tanpa membayar atau naik bus tanpa membeli karcis. k) Turut dalam pelacuran atau melacurkan diri baik dengan tujuan kesulitan ekonomi maupun tujuan lainnya.

1) Berpakaian tidak pantas dan minumminuman keras sehingga merusak diriny amaupun orang lain.

2) Kenakalan yang bersifat melanggar hukum dengan penyelesaian sesuai dengan undang-undang dan hukum yang berlakusama dengan perbuatan melanggar hukum bilamana dilakukan oleh orang dewasa yaitu:

a) Perjudian dan segala macam bentuk perjudian yang mempergunakan uang.

b) Pencurian dengan kekerasan maupun tanpa kekerasan: pencopetan, perampasan, dan penjambretan.

c) Penggelapan barang.

d) Penipuan dan pemalsuan.

e) Pelanggaran tatasusila, menjual gambar-gambar porno dan film porno,serta pemerkosaan.

f) Tindakan-tindakan anti sosial, perbuatan yang merugikan milik oranglain.

g) Percobaan pembunuhan.

h) Pengguguran kandungan.

Berdasarkan hasil observasi yang peneliti temukan di lapangan bahwa terdapat berbagai macam bentuk-bentuk perilaku meyimpangan yang dilakukan oleh siswa di SDN 350 Kahaya Kecamatan Kindang Kabupaten Bulukumba antara lain:

a. Perkelahian

Perkelahian merupakan bentuk penyimpangan yang paling banyak dilakukan siswa di di SDN 350 KahayaKecamatanKindang Kabupaten Bulukumba.Hal ini dikarenakan adanya selisih paham antara siswa yang satu dengan siswa yang lainnya atas sesuatu sehingga memicu perkelahian antar siswa.

Adapun sanksi yang diberikan dari pihak sekolah adalah panggilan terhadap kedua orang tua siswa yang bertikai kemudian ditambah dengan hukuman ringan yakni menghapal perkalian dan membaca surah-surah pendek.

\section{b. Membolos}

Perilaku menyimpang ini adalah perilaku menyimpang yang paling banyak di lakukan oleh siswa yakni membolos. Salah satu faktor dominan yang menjadi pemacu siswa untuk membolos adalah rasa malas mengikuti proses 
pembelajaran.Perbuatan membolos ini bukanlah perkara hukum melainkan perkara yang bersifat asosiasi dan amoral. Seperti yang dinyatakan SinggihD. Gunarsa (2003:20) bahwa membolos termasuk "Kenakalan yang bersifat amoral dan asoiasi, karena tidak diatur dalam undang-undang sehingga tidak dapat atau sulit digolongkan sebagai pelanggaran hokum".

Aksi membolos dilakukan oleh siswa di di SDN 350 Kahaya Kecamatan Kindang Kabupaten Bulukumba karena malas mengikuti pelajaran dan malas mengerjakan pekerjaan rumah (PR).Adapun sanksi yang diberikan oleh pelanggar yaitu membuat pernyataan tidak akan bolos lagi dan akan rajin mengerjakan PR (ditulis sebanyak 100 kali).

c. Keluyuran

Sama halnya dengan membolos, keluyuran juga merupakan perkara yang bersifat amoral dan asosiasi dan bukan perkara hokum. Singgih D.Gunarsa (2003:20) menyatakan bahwa "Keluyuran, pergi sendiri maupun berkelompok tanpa tujuan dan mudahmenimbulkan perbuatan iseng yang negatif."

Keluyuran yang dilakukan oleh siswa di SDN 350 Kahaya Kecamatan Kindang Kabupaten Bulukumba adalah beperigian saat jam pelajaran sedang berlangsung. Keluyuran terjadi karena adanya saling mempengaruhi antara siswa yang satu dan siswa yang lainnya untuk tidak mengikuti pelajaran tertentu.Adapun sanksi yang diberikan oleh pihak sekolah adalah pembinaan dari guru kelas.

\section{SIMPULAN DAN SARAN}

\begin{tabular}{ccccc}
\multicolumn{2}{c}{ Bentuk-bentuk } & penyimpangan & yang \\
dilakukan siswa & di & SDN & 350
\end{tabular} KahayaKecamatanKindang Kabupaten Bulukumba antara lain: berkelahi, bolos, keluyuran. Munculnya perilaku menyimpang siswa di SDN 350 Kahaya Kecamatan Kindang Kabupaten Bulukumba.kerap kali terjadi karena adanya saling mempengaruhi antara siswa yang satu dengan siswa yang lainnya.

Berdasarkan kesimpulan diatas, peneliti menyampaikan saran-saran kepada: (1). Kepala SDN 350 Kahaya Kecamatan Kindang Kabupaten Bulukumba untuk selalu menekankan kedisiplinan kepada seluruh warga sekolah untuk mengurangi timbulnya penyimpanganpenyimpangan di dalam lingkungan sekolah;
(2). Bagi pendidik di SDN 350 Kahaya Kecamatan Kindang Kabupaten Bulukumba untuk selalu memberikan contoh yang baik dan semestinya kepada seluruh siswa, melakukan pengawasan dengan ketat sehingga tidak ada celah bagi seluruh warga sekolah untuk melakukan pelanggaran; (3). Bagi siswa untuk selalu patuh terhadap peraturan dan tata tertib sekolah sehingga tidak banyak lagi yang membuat pelanggaran di sekolah.

\section{DAFTAR RUJUKAN}

Ali, Mohammad dan Mohammad Asrori. 2012. Psikologi Remaja Perkembangan Peserta Didik. Cet. VIII. Jakarta: Bumi Aksara.

Daradjat, Zakiah. 1968. Membina Nilai-Nilai Moral Indonesia. Jakarta: Bulan Bintang.

Fitri, Agus Zaenul. 2012. Pendidikan Karakter Berbasis Nilai dan Etika di Sekolah. Jogjakarta: Ar-Ruzz Media.

Gerungan. 2004. Psikologi Sosial. Bandung. Refika Ditama

Gunarsa, Ny. Singgih. 2003. Psikologi Remaja. Jakarta: Gunung Mulia.

Kartono, Kartini. 1998. Patologi Sosial 2 Kenakalan Remaja. Jakarta: PT. RajaGrafindo Persada.

Mulyono, Y. Bambang. 1993. Pendekatan Analisis Kenakalan Remaja dan Penanggulangannya. Penerbit Kanisus: Yogyakarta.

Nawawi, Hadari. 1998. Metode Penelitian Bidang Sosial.Yogyakarta: Gajahmada University Press.

Sadli, Saparinah. 1976. Persepsi Sosial Mengenai Perilaku Menyimpang. Jakarta: Bulan Bintang.

Santoso, Topo dan Zulfa, Eva A. 2005.Kriminologi.Jakarta : PT RajaGrafindo Persada.

Sarwono, Wirawan. 1998. Psikology Remaja. Jakarta: PT. Raja Grafindo Persada. 
Sekarningsih, Renny. 1983. Pengantar Pekerjaan Sosial. Bandung: UNPAD

Soekanto, Soerjono. 1988. Sosiologi Keluarga. Jakarta: Rineka Cipta.

Sugiyono.2009. Metode Penelitian KuantitatifKualitiatif dan R\&D. Bandung Alfabeta.

Sunarto. 2004. Pengantar Sosiologi. Jakarta: Pratama Rahardja.

Suyanto, Bagong dan J. Dwi Narwoko (ed). 200 6. Sosiologi Teks Pengantar dan Terapan, Jakarta: Kencana

Taniputra, Ivan. 2005. Psikologi Kepribadian. Yogyakarta: Ar-Ruzz Media.

Wardati dan Mohammad Jauhar.2011. Implementasi Bimbingan Konseling dan Konseling di Sekolah. Jakarta: Prestasi Pustaka Publisher.

Undang-Undang No.20 Tahun 2003 Pasal 3 Tentang Sistem Pendidikan Nasional

Marwati, Dwi. 2005. "IMPLEMENTASI KURIKULUM Kurikulum SMK Edisi 2004 Melalui Pendekatan Kurikulum Berbasis Kompetensi pada Matadiklat Siklus Akuntansi (Studi Kasus di SMK Yapek Gombong Kabumen Tahun Pelajaran 2004/2005)". Skripsi S1. Univesitas Negeri Semarang. 